\title{
高龄者循環器疾患患者の運動量と知的精神機能の相関性について
}

\author{
佐 藤 恒 久* 櫻井伊 三** 宮 城 憲 一* \\ 宝 積 克 彦***富 田 泰*

\section{CORRELATION BETWEEN EXERCISE AND PSYCHIATRIC FUNCTION IN AGED PATIENTS WITH CIRCULATORY DISEASE}

\author{
Tsunehisa Satoh, Izo Sakurai, Kenichi Miyagi, \\ YoshiniKo HoHShaKU and YasUShI TOMITA
}

\begin{abstract}
Senile patients with heart disease were evaluated in order to study the correlation between their mental and physical activities in daily life. Mental activity was classified using Hasegawa's dementia scale, and physical activity was measured by the number of steps per day recorded with a passimeter. It was found that;

1) Hasegawa's dementia score was positively related to the number of steps.

2) Hasegawa's dementia score was significantly increased after walking training for 1 year.

Thus it is suggested that appropriate physical exercise is necessary for maintaining or increasing mental activity in aged patients with circulatory disease.
\end{abstract}

(Jpn. J. Phys. Fitness Sports Med. 1991, $40: 121 \sim 126$ )

key words : Exercise, Psychiatric function, Reversible dementia

I. 緒

言

急性心能梗塞発症後 1 ケ月前後で知的精神機能 の低下をきたす症例は稀ではない。これらの循環 器疾患患者の心機能回復に関する報告 ${ }^{11,15)}$ は, 少 なくない，しかし，知的精神機能低下あるいは老 年期疾呆について，運動の効果に関する報告は， ほとんど見当たらない。また，老年期痴呆は，神 経病理学的所見, 頭部 CT 所見の経過から多くは 進行性であるが，脳病変は必ずしも非可逆的では ないとする報告も1980年代より出現し，最近では 痴朵の非可逆性という概念は取り外されたとする 報告91 もある. 私たちは, 高龄者循環器疾患患者 が, 安静臥休の結果低下した知的精神機能が, 歩
行訓練によって回復する症例を少なからず経験し ている. そこで, 安静臥床の多、循環器疾患患者 の知的精神機能と運動量の関連性さらに精神機能 の可逆性について検討した.

\section{II. 方法}

対象は, 1988年に大生病院において, 治療を受 けている70才以上 $(78.4 \pm 7.6 才) の$ 循環器疾患患者 36名である.な拉，性別は男性12名，女性24名で ある.このうち 1 年間の経過を観察し得た症例は, 男性 5 名，女性17名の合計22名である。これらの 症例は, 陳旧性心筋梗塞 (OMI) の有無ならびに 入院と外来診療の 4 項目の組み合わせによって 4 群に分類した。なお，これらの症例には脳血管障

*聖マリアンナ医科大学東横病院内科 Toyoko Hospital, St. Marianna University School of Medicine,

川崎市中原区小杉町3-435

**自衛隊中央病院研究検査部 世田谷区池尻1-2-24

***大生病院 㹟山市水野594
3-435, Kosugicho, Nakahara-ku, Kawasaki 211

Self-Defence Force Central Hospital, 1-2-24, Ikejiri, Setagaya-ku, Tokyo

Taisei Hospital, 594, Mizuno, Sayama, Saitama 
害患者は含まれていない。

これらの患者に対して，運動量推定のための万 歩計による 1 日の歩行数記録, ならびに長谷川式 簡易知的評価スケールマにより知的精神機能を測 定した後, 機能訓練士によって，機能訓練として の歩行訓練を 1 年間実施した. その後, 再び前述 の検査を施行した．なお，全症例を長谷川式簡易 知的評価スケールのスコアによりつぎの 4 群に分 類した. すなわち, normal 群 : 31.0以上, subnormal 群: 30.0-22.0, predementia 群: 21.5-10.5, dementia 群 : 10.0以下である.なお, 満点は, 32.5 点である.

また，1988年の調査開始時には，36名全員に対 して，ホルター心電計による心電図の観察，なら びに脳動脈硬化症との関連性がある血清脂質のう ち, 中性脂肪 ( $\mathrm{TG}$ ) と高比重リポ蛋白コレステロ ール (HDL-Cho) について測定した.

\section{III. 結果}

調査対象となった各群の心電図の観察結果を表 1 亿示した。上室性期外収縮 (SVPB)，心室性期 外収縮 $(\mathrm{VPB})$ ともに，24時間で 100 beats 以上を もってプラスと判断した。 まず，陳旧性心筋梗塞 (OMI)の患者では, 入院群が SVPB, VPB ともに
Table 1. Changes of supraventricular premature beat (SVPB), ventricular premature beat (VPB), ST-segment and $\mathrm{T}$ wave by Holter ECG in four groups. OMI indicates old myocardial infarction.

\section{Arrhythmias and Ischemic Change}

\begin{tabular}{rccc} 
& SVPB & VPB & ST. T change \\
\hline inpatients with OMI & 4 & 4 & 8 \\
without OMI & $(44.4 \%)$ & $(44.4 \%)$ & $(88.9 \%)$ \\
& $(61.5 \%)$ & $(38.5 \%)$ & $(46.2 \%)$ \\
outpatients with OMI & 2 & 2 & 2 \\
& $(100 \%)$ & $(100 \%)$ & $(100 \%)$ \\
without OMI & 4 & 2 & 6 \\
& $(36.4 \%)$ & $(18.2 \%)$ & $(54.5 \%)$ \\
\hline
\end{tabular}

44.4\%，虚血性 ST, $\mathrm{T}$ 変化では 88.9\%であるのに 対して, 外来群では, SVPB, VPB および ST, T 变化は三者ともに $100 \%$ \%でった。つぎに，陳旧 性心筋梗塞の既往のない患者についてみると，入 院患者群では，三者(SVPB, VPB, ST, T 変化) の値は, $61.5 \%, 38.5 \%, 46.2 \% て ゙ あ り ，$ 外来患者 群では， $36.4 \% ， 18.2 \% ， 54.5 \%$ であった。

知的精神機能 ( 4 群) と運動量 ( 1 日歩行数) との 関連は，図1飞示した。すなわち，左側のグラフ Aが1988年度に実施したものであり，右側のグラ
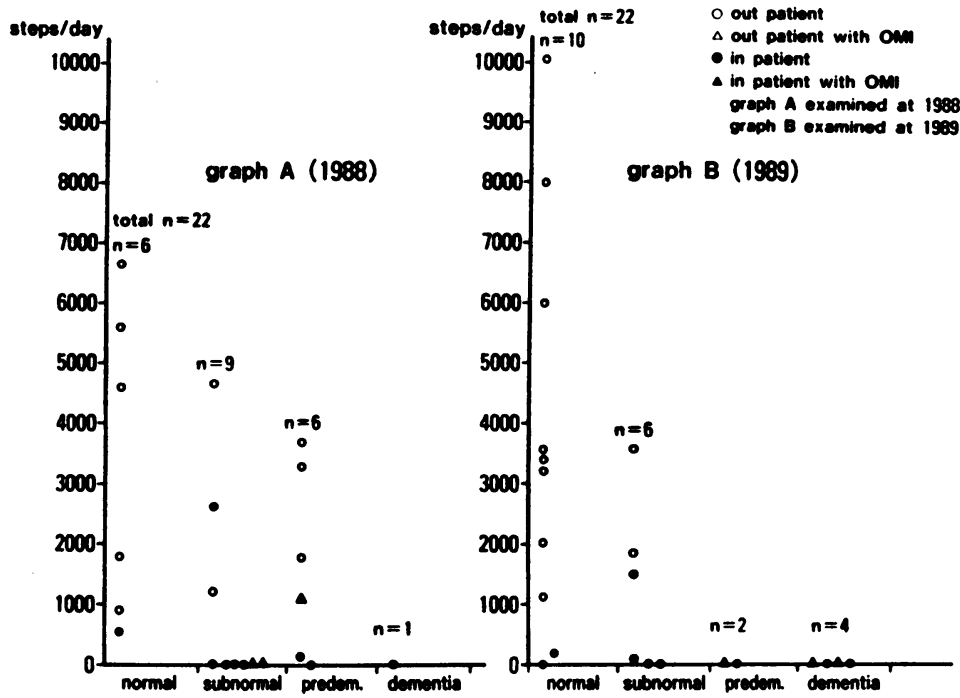

Fig. 1. Relation between Hasegawa's dementia scale and steps about aged circulatory patients. Graph A indicates the result of 1988, and Graph B is 1989. 
フ B は， 1 年後の1989年度の結果である．まず， グラフAについてみると, normal 群では 6 名全 員が OMI の既往のない患者であり, 唯一の入院 患者が 1 日 500 歩である以外は，全員 1 日 900 歩 以上の運動量であった. subnormal 群では，9名 中 3 名は 1000 歩以上の運動量を記録し，他の 6 名 は OMI 既往の有無にかかわらず, 1 日の運動量 がほとんどゼロであった. predementia 群は， 6 名中 4 名が 1 日 1000 歩以上の比較的多い運動量を 示したが，これらは，徘䧃癖を有する患者であっ た.なお， dementia 群と判定された者は22名中 1 名で歩行の意欲もなかった.

つぎに，これらの症例の 1 年後の結果であるグ ラフBについてみると, subnormal 群, predementia 群の患者がグラフA (前年)に比べて減少 し, normal 群, dementia 群が増加した. とくに predementia 群で著しく, dementia 群と问様に, これらに分類された患者の運動量はゼロであっ た、しかも, predementia 群, dementia 群の症 例では, OMI 既往の有無にかかわらず 6 名全員入 院患者であるのに対して, normal 群, subnormal 群では16名全員が OMI の既往のない患者であっ た。ささらに, OMI 既往の有無にかかわらず, 入院 患者では, subnormal 群の 1 名を除き，すべての
群に掞いて運動量はほとんどゼロであった。

図 2 は, 知的精神機能と運動量の関連の 1 年間 の推移を各患者ごとに示したものである.normal

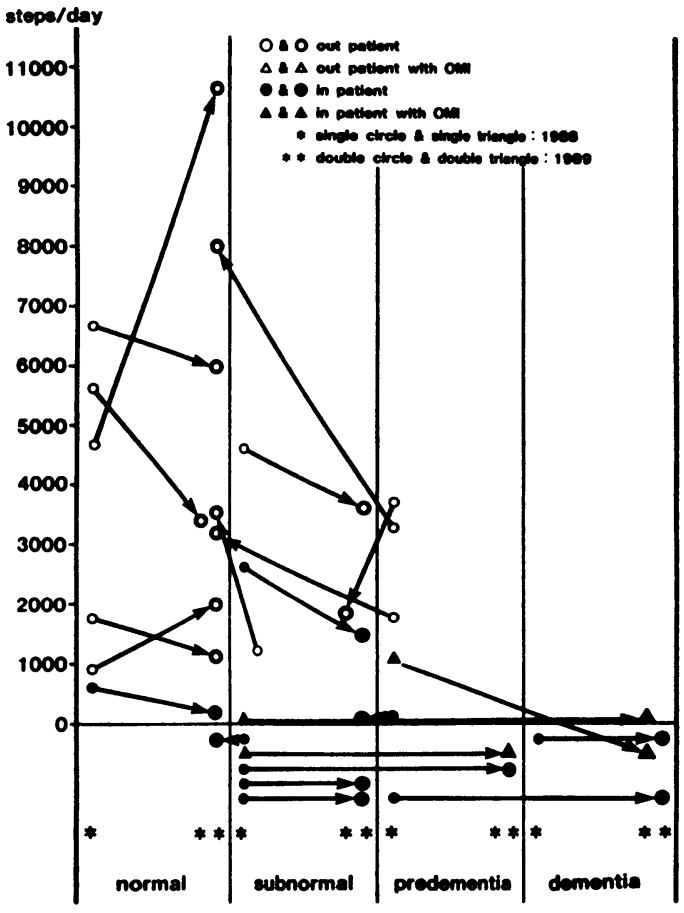

Fig. 2. A year follow-up of Hasegawa's demen. tia scale and steps of each patient.

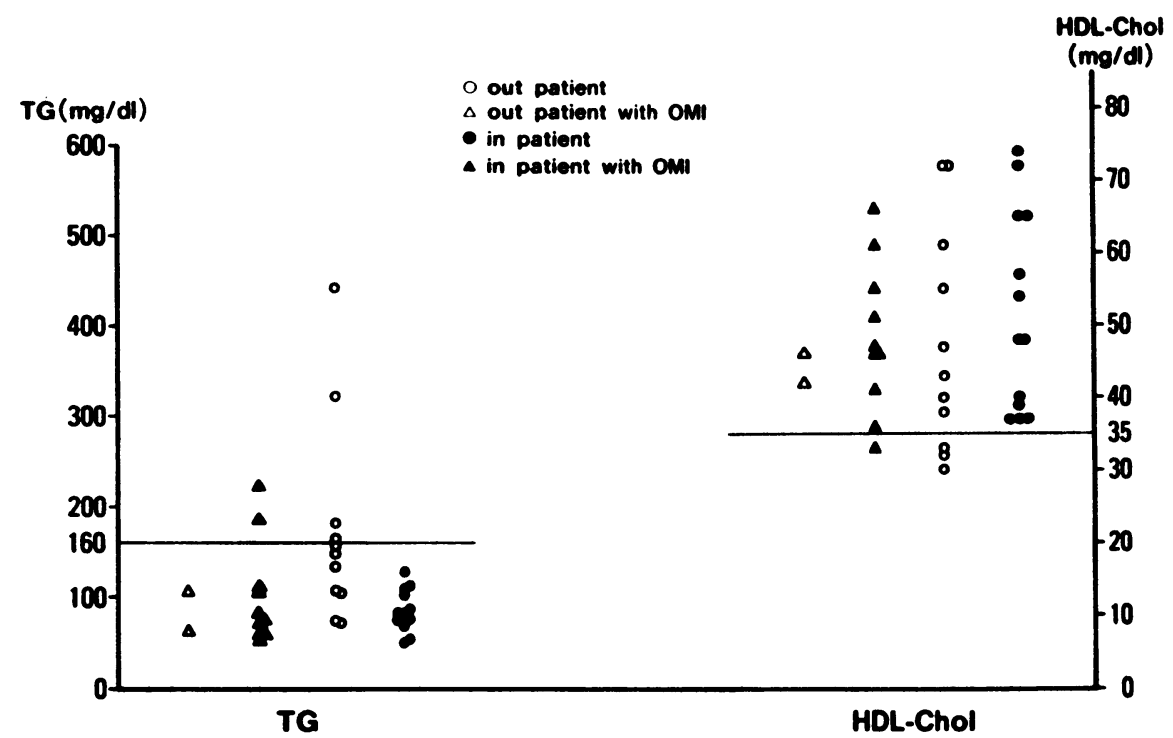

Fig. 3. Serum levels of triglyceride (TG) and high density lipoprotein cholesterol (HDLChol) in each group. 
群では, 6 名中 4 名が 1 年後には歩行数が低下し ているのにもかかわらず, 6 名全員が normal 群 に属している. subnormal 群では，前年より運動 量が増加した外来患者は知的精神機能 が normal 群へ回復し, 歩行数が 1000 歩以上の他の 2 例では, 不変であった. しかし, 歩行数が1000歩以下では, 不変の者 2 例, dementia 群へ 1 名, predementia 群へ 2 名と精神機能は低下を示した。つぎに predementia 群では, 運動量が1000步以上であっ た 3 例のうち 2 例は normal 群に， 1 例は subnormal 群へと精神機能の回復を示した. 一方, 1000歩以上の歩行から，ほとんど歩行しなかった 1 例では, dementia 群へと悪化を示した.なお， ほとんど步行しないにもかかわらず, predementia 群から subnormal 群へあるいは, subnormal 群から normal 群へと知的精神機能の回復した症 例もみられた。

TG と HDL-Chol の測定結果を各群ごとに示 したのが図 3 である. TG の $160 \mathrm{mg} / \mathrm{d} l$ および HDL-Chol $35 \mathrm{mg} / \mathrm{d} l$ は，当病院に打けるそれぞ れの正常上限值および正常下限值である. TG に ついてみると，入院患者(黒印)では，OMI 既往の ある患者 2 例を除き大部分は正常であった．これ に対して，OMI 既往のない外来患者群では, やや 高い傾向がみられた。一方, HDL-Chol は, OMI 既往のある患者では，1名を除き正常であった。 これに対して, OMI 既往の無い症例では, 外来群 の 3 名が異常值を示したのみで大部分は正常であ った.

\section{IV. 考察}

步行によって, 高澮者循環器疾患患者の知的活 動が活発になることが明かになった. したがって 少なからず危険を伴い，または意欲のない患者で も積極的に歩行訓練，機能訓練を施行すべきであ る. また，老年痴呆は脳の器質的変化を伴うもの であるが私たちの症例では, 少なくとも predementia 群までの患者は知的精神機能が可逆的 に改善された。

この事実は, Albert ら", McHugh \& Folstein $^{12)}$, Cummings \& Loverme ${ }^{3)}$ の痴呆の治療に
関する報告と一致している. 内島ら ${ }^{151}$ は, 運動負 荷による心䇗梗塞患者の心機能への影響をみてい るが，60才以上の高路者では運動負荷による心機 能の改善は認められないが，精神機能に与える影 響は大さいと報告している，このような傾向は， 竹井ら ${ }^{14}$ による高龄者の大腿骨頸部骨折患者にお ける自宅療養群と施設群の長谷川式簡易知的評価 スコアの比較でも, 自宅療養群に比較して日常の 行動範囲が限定される後者の方が明らかに低い傾 向を示している.

Katzman ら ${ }^{81}$ は, 75 85才の老人 434 人を 5 年 間追跡し, 56 人 $(12.9 \%)$ dementia になったが, dementia 発症の危険因子として，80才以上の女 性, 糖尿病, 左室肥大などのほかに心筋梗塞発症 後に dementia になるケースを報告している. さらに血清中の HDL-Chol, および TG と dementia の関連を調べているが，私たちの結果と 同様に, dementia とは有意な相関を認めなかっ たと報告している.

しかし，安静臥床によって自発的意欲を失い， 不活発になる高龄者循環器疾患患者では, らつ病 性痴呆 (depressive pseudodementia)の状態にな るとする報告もある ${ }^{5,13)}$. Schleifer ら ${ }^{131}$ は, 283名 (27〜90才) の心筋梗塞患者について, CCU 入室 8 日から10日目に，らつ状態を測定するために Hamilton depressive scale ${ }^{6}$ を実施したところ, 45\%が抑らつ傾向を示し，そのうち $18 \%$ は真のう つ病であったが, らつ状態の生起率と心筇梗塞の 重症度との間に相関が認められなかったと報告し ている.一方 Kral ら ${ }^{10)}$ によると老跲者のうつ病性 仮性痴呆は多くの症例に沶いて, Alzheimer 型老 年痴呆の前兆であり，らつ病を対象に治療を実施 しても，数年から10数年後には約 $90 \%$ 老年疾呆 へと進行したと報告している.ささらに, 老年知呆 では病初期に，らつ状態を呈することがよくあ り，老人の知的精神機能の低下が，らつ状態によ る仮性痴呆なのか，あるいは痴呆による仮性うつ 病なのかを鑑別するのは必ずしも容易なことでは ない.この点に関して, Folstein \& McHugh")は, らつ病と痴呆の発生機序に共通した脳内の生化学 的变化を推定している. 
ところで，1980年代には回復可能な痴呆 (reversible dementia $)^{3)}$, 治療可能な痴呆( treatable dementia $)^{2)}$ といら用語が出現し, 最近では, 痴 呆の非可逆性といら規定が取り外されるようにな った.すなわち, 我々の結果でも 1 年間の運動療 法後に可逆的に長谷川式簡易知的評価スケールの 得点が高くなった症例がみられた。しかし，これ らの精神機能が向上した症例のうち何例かは, 初 回の調查時にうつ病性仮性痴朵の状態であったと 言う可能性も充分考えられる. 今後, 老人痴呆の 他にうつ病性仮性痴呆について子検討するつもり である。

\section{V. 結語}

70才以上の高齢者循環器疾患患者を対象に, 万 歩計による 1 日の運動量の测定ならびに長谷川式 簡易知的評価スケールにより知的精神機能を測定 し，両者の関連性を観察した。さらに，1年間の 歩行訓練を施行し, 運動量の变化による知的精神 機能の推移を検討し，以下の結果を得た.

1. 長谷川式簡易知的評価スケールで分類した 4 群の 1 日 1000 歩以上の歩行者百分率は下記のと おりである.

$\begin{array}{lll}\text { normal 群 } & 10 \text { 例 } & (80 \%) \\ \text { subnormal 群 } & 3 \text { 例 } & (50 \%) \\ \text { predementia 群 } & \text { 無し } & (0 \%) \\ \text { dementia 群 } & \text { 無し } & (0 \%)\end{array}$

2. predementia 群までは, 1 日1000歩以上の 歩行によって知的精神機能は回復した. しかし, 1000歩以下の症例については, 知的精神機能は低 化した.

3. dementia 群の症例は, ほとんど步行せず 知的精神機能も回復しなかった.

4. 血清 TG および HDL-Chol と dementia との閒に関連性は認められなかった。

以上の結果より, 安静を必要とする循環器疾患 患者においても，適度な運動が，知的精神機能の 維持, 回復に不可欠であることが示唆された.

(本論文の要旨は, 第43，44回日本体力医学会大 会において発表したものである)

(受付 平成 2 年 6 月 12 日)

\section{文献}

1) Albert, M., Feldman, R. G. and Willis, A. L.(1974): The subcortical dementia of progressive supranuclear. J. Neurosurg. Psychiatry, 37, 121-130.

2) Benson, D. F. (1982): The treatable dementia. In Psychiatric aspects of neurogic disease, ed. by Benson D. F., Blumer D., Vol. 11, 123, Grunne \& Stratton, New York.

3) Cummings, J. L., and Loverme, S. Jr. (1980) : Reversible dementia. JAMA, 243, 2434-2439.

4) Folstein, M. F. and McHugh, P. R.(1978): Dementia syndrome of depression. In Alzheimer's disease, ed. by Katman, R., Terry, P. D., Bick, K. L., Senildementia and related disorders, 87-93, Raven Press, New York.

5) Hackett, T. P. (1985) : Depression following myocardial infarction. Psychosomatics, 26, 23-28.

6) Hamilton, M. (1967) : Dvelopment of a rating scale for primary depressive illness. Br. J. Soc. Clin. Psychol., 6, 278-296.

7) 長谷川和夫, 井上勝也, 守屋國光 (1974) : 老人の痴 呆彰査スケールの一検討. 精神医学, 16, 956-969.

8) Katzman, R., Aronson, M., Fuld, P., Kawas, C. (1989) : Development of dementing illnesses in an 80-year-old volunteer cohort. Ann. Neurol., 25, 317-324.

9) 小坂憲司 (1988) : 痴呆の初期診断と臨床症状. 臨床 精神医学, 17(11), 1567-1575.

10) Kral, V. A. and Emery O. B.(1989) : Long-term follow-up of depressive pseudodementia of the aged. Can. J. Psychiatry, 34, 445-446.

11) 桑原敏樹, 丸岡隆芳, 内田宏子, 内島 弘(1984): 陳旧性心筋梗塞症の低温, 高温環境における定量的 運動負荷試験の検讨. リ八医学, 21(5), 333-339.

12) McHugh, P. R. and Folstein, M. F. (1975) : Psychiatric syndoromes of Huntington's chorea : a clinical and phenomenologic stundy. In Psychiatric aspects of neurologic disease, ed. by Benson D. F., Blunner, D. 1267-1286, Grnne \& Stratton, New York.

13) Schleifer, S. J., Macari-Hinson, M. M., Coyle, D. A. and Slater, WR.(1989): The nature and course of depression following myocardial infarction. 
Arch Intern Med. 149, 1785-1789.

14）竹井通博, 林 嘉昌, 鍋島隆治, 姜 武(1985)： 老人の大腿骨頸部骨折と予後判定一長谷川式痴呆テ スト，脳波。心電図検査からみた．Hip. Joint. 11,
23-27.

15) 内島 弘, 新村与平, 丸岡隆芳, 林 正博(1981): 運動負荷試験による心筋梗塞患者の退院後の心機能 経過について. リ八医学, 18(1), 37-43. 